\title{
Can the Green Economy deliver it all? Experiences of renewable energy policies with socio-economic objectives
}

\author{
Michael Pahle $\mathrm{a}^{\mathrm{*}}$, Shonali Pachauri ${ }^{\mathrm{b}}$, Karoline Steinbacher ${ }^{\mathrm{cd}}$ \\ *Corresponding author: michael.pahle@pik-potsdam.de \\ aPotsdam Institute for Climate Impact Research (PIK), PO Box 6012 03, 14412 Potsdam, Germany \\ bInternational Institute for Applied Systems Analysis (IIASA), Laxenburg, Austria \\ 'Energy Technology Innovation Policy Group, Belfer Center for Science \& International Affairs, Harvard Kennedy School, USA \\ dEnvironmental Policy Centre, Freie Universität Berlin, Germany
}

Abstract: The Green Economy (GE) paradigm aims to reconcile environmental and socio-economic objectives. Policies to deploy renewable energy (RE) are widely perceived as a way to tap the potential synergies of these objectives. It is, however, still largely unclear whether the potential of simultaneously achieving both environmental and socio-economic objectives can be fully realized, and whether and how multiple objectives influence policy design, implementation, and evaluation. We aim to contribute to this aspect of GE research by looking at selected country experiences of renewable energy deployment with respect to the socio-economic goals of job creation or energy access. Across the cases examined, we find the following implications of relevance for the GE framework: First, we confirm the important role of governmental action for GE, with the specific need to state objectives clearly and build monitoring capacity. Second, consistent with the "strong" green growth variant of $\mathrm{GE}$, some of the cases suggest that while renewable deployment may indeed lead to short-term socio-economic benefits, these benefits may not last. Third, we underline the urgent need for new methodologies to analyze and better understand multiple-objective policies, which are at the heart of the GE paradigm.

Acknowledgments: The authors would like to thank Luis Mundaca, three anonymous reviewers and the editor for very helpful comments, and Oliver Tietjen for research assistance. The research leading to these results has received funding from the European Union's Horizon 2020 research and innovation program under grant agreement No 642147 (CD-LINKS) and from Italy's Ministry for Environment, Land and Sea in the framework of a Giorgio Ruffolo Fellowship at the Harvard Kennedy School's Belfer Center for Science and International Affairs. 


\section{Introduction}

One of the main premises of the "Green Economy" (GE) concept is that low-carbon energy technologies have considerable potential to achieve socio-economic objectives alongside environmental ones. In essence, the GE paradigm promises a new holistic model of societal wellbeing. This is evident from UNEP's definition of the concept: A green economy "results in improved human well-being and social equity, while significantly reducing environmental risks and ecological scarcities" (UNEP 2011). However, GE is a relatively vague concept that builds on a number of implicit assumptions, which have been scrutinized in scientific literature. In this regard, Bowen \& Hepburn (2014), largely based on Jacobs (2013), identify two forms of green growth (GG), which can be seen as more specific versions of a GE. "Standard" green growth concepts postulate that green (i.e. environmental) policies will reduce economic growth in the short run, but increase it in the long run. In contrast, "strong" green growth asserts that green policies can also increase economic growth in the short run. Bowen \& Hepburn (2014) further claim that from a theoretical point of view, strong green growth may only hold under one of the following conditions: (a) if, during an economic downturn, green policies provide an important stimulus for economic recovery ("green Keynesianism"); (b) if green policies explicitly address existing market failures, for example an inadequate provision of infrastructure; or (c) if green policies incentivize entrepreneurs to establish competitive advantage in green technologies and services through associated innovation.

Apart from its dependence on specific assumptions, the concept of $G G$ is also questioned on fundamental grounds. First, critics of the so called "growth imperative" like Daly (2013) question whether growth - green or otherwise - can actually increase wealth, or at least increase it faster than illth. Jakob \& Edenhofer (2014) question whether growth in general, as well as de-growth as an alternative, are useful approaches at all. They reason that growth as an approach fails to explicitly identify the objectives that should ultimately be achieved via economic growth. In other words, they see growth as a means, rather than as an end, to achieve societal welfare. One implication of this stance for the GG and GE concepts is the necessity to specify policy objectives, so as to evaluate the performance of green policies in achieving them. The most important reference here is certainly the Sustainable Development Goals (SDGs), not least because it has been explicitly argued that a GE is essential for sustainable economic development (Barbier \& Markandya 2013). We therefore depart from a focus on growth as a metric to assess the relevance of the GE concept in policy-making and look at the interlinkages between renewable energy policies and jobs as well as energy access.

The above GE literature raises several important questions that motivate this paper and are addressed in four exploratory case studies. First, to what extent do green policies explicitly target socio-economic objectives or are even driven by these objectives? For instance, empirical evidence suggests that RE deployments, particularly in developing countries, are often implemented as socioeconomic policies; see for example Recalde (2015) on Latin America and Steinbacher (2015) on Morocco. This is important because formulated or intended objectives obviously determine how policies are designed and evaluated, and are also likely to affect how they perform in achieving multiple objectives. In fact, this issue of multi-objective policies is as yet largely unexplored in the literature. A second relevant aspect with a view to the "strong" green growth concept outlined above is to explore whether green policies are able to bring about socio-economic benefits in the short to mid term - and not only in the long term. Against this background, we aim to look at several countries' experiences along these two lines of inquiry - the role of multiple objectives in policy design and stated short-term benefits in terms of outcomes - and reflect upon their implications for 
GE and GE research. We aim to add value to the GE debate by covering heterogeneous cases - South Africa, Germany, Morocco, and Kenya - and derive lessons learned from these countries. Our aim is exploratory in nature and we do not strive to judge or evaluate policy effects in particular cases.

Specifically, we focus on policies for the deployment of renewable energy and two socio-economic objectives identified by SDG 7 and 8, namely the provision of energy access and job creation. According to UNEP (2011), low-carbon technologies - particularly renewable energies in the electricity sector (RE) - bear considerable potential for making progress towards these and other objectives, such as public health and energy security. The IEA (2013) emphasizes the role of RE in achieving universal access to modern energy sources by 2030, while IRENA (2016) underlines their potential for job creation. The socio-economic dimension of RE is also acknowledged in climate change science and global policy debates. In particular, the recent IPCC AR5 (2014) finds that measures to deploy RE are often associated with other societal goals - and a positive interaction is believed to create the possibility of "co-benefits."

Existing research on analyzing the potential of job creation or energy access through RE policies are largely model-based ex-ante assessments. A number of existing studies cover the potential of job creation through clean energy policies, both in developing and in developed countries; see for example Dai et al. (2016), Bowen \& Kuralbayeva (2015) and the studies cited in IPCC (2012), OECD (2010), and GIZ (2015). Most of these studies focus on gross employment and suggest that an expansion of RE has positive effects. A smaller number of studies, using more sophisticated models, analyze net employment impacts, and the results of these also suggest that effects are positive. A notable exception, contrasting policy targets with outcomes, is Rathmann et al. (2012), who look at the Brazilian biodiesel program and find that the "promised land" has not been reached. From a theoretical point of view, Fankhauser et al. (2008) point out that gross employment can indeed be positive for two reasons: First, sectors immediately related to RE production are likely to expand. Second, these sectors are, in general, more labor intensive than traditional industries. The authors, however, also underline that direct employment gains are likely to diminish when technologies become mature. Long-term employment can, however, be sustained when RE expansion is successful as a green industrial policy, i.e. in building up an industry that is globally competitive (e.g. Rodrik 2014).

Concerning energy access, several studies point to the large potential of decentralized RE for electrification, especially in rural areas (IPCC 2012, REN21 2014). However, initiatives for distributed renewable energy face a distinctive set of technical, policy, financial, institutional, and regulatory challenges (Palit 2013; WRI 2015). Several studies have identified the main barriers to the deployment and uptake of small-scale renewables; see for example Chaurey \& Kandpal (2010), Sovacool et al. (2011), IOB (2014) and Urpelainen (2016) specifically for solar home systems (SHS). For these reasons it is widely assumed that grid connection is generally preferred as an option where it is feasible (van der Vleuten et al. 2007). Intermittency and capacity constraints of RE systems can also limit the extent to which they can satisfy commercial and productive needs, or increasing demands associated with growing appliance use. Even in areas where renewables-based options are competitive, they may still be unaffordable for poor rural households. Innovative business models or financing may be needed to make these affordable. While off-grid renewables are becoming increasingly competitive with grid-based systems, particularly in remote rural regions, the fraction of population whose demand will be met through such systems remains open to debate (Deichmann et 
al. 2011; Zeyringer et al. 2015), and evidence on impacts is still insufficient (Jürisoo et al. 2014; Azimoh et al. 2015; Rao et al. 2016).

In summary, there are gaps in the literature regarding the realization of the seemingly high potential and respective expectations of RE's contribution to socio-economic objectives. Studies in this direction are so far relatively sparse in the literature; this is particularly the case for large-scale RE deployment policies that are still a relatively new development.

The remainder of this paper is structured as follows: Section 2 describes the methodology used. Section 3 covers the case studies on RE policies and job creation in Germany and South Africa, while section 4 covers the Moroccan and Kenyan case studies on the deployment of renewables for energy access. Section 5 discusses the key findings from the case studies for the GE paradigm and Section 6 concludes.

\section{Methodology}

Given the lack of empirical studies that specifically look at the links between renewable energy policies and socio-economic objectives, our aim in this paper is to cover a diverse range of cases in an exploratory manner and thereby help prepare the ground for more in-depth studies. In other words, our overarching aim is to grasp and present country experiences with the design and implementation of policies at the intersection of renewable energy promotion and socio-economic objectives. By doing so, we also strive to identify common patterns across these diverse cases and to link them back to the theoretical green economy debate. Importantly, we do not conduct original evaluation of any specific policy, which would be beyond the scope of this paper.

Methodologically, we approach the question of interlinkages between RE policies and socioeconomic objectives by adopting a "multiple-case" design (Yin 2009: 48). In this design, several processes and events are taken into account within each case study. Cases are looked at separately in a first step and are then compared in a second step. Case studies are described by Gerring (2004) as "an intensive study of a single unit with an aim to generalize across a larger set of units." Of course, the confines of this paper and our decision to address four diverse cases limit the depth to which each case can be studied, as well as generalization of respective findings. Within each case study, we mainly rely on a review of secondary sources (e.g. policy documents, statements, evaluations, analysis from in-country experts regarding the programs). In South Africa, primary data from sixty interviews carried out with stakeholders and decision-makers in late 2014 was also used (Steinbacher forthcoming). Not relying on original research and making use mostly of gray literature of course limits the validity of results somewhat. Accordingly, we only claim indicative evidence in each case, which requires further peer-reviewed scientific research to be confirmed and better understood.

Case selection in this paper is based on a set of criteria that make Germany, South Africa, Morocco, and Kenya important cases for further hypothesis generation and theory building in the GE literature (on case studies and inference see George \& Bennett 2005 and Levy 2008). First, initial caseknowledge suggests multiple policy objectives are likely to have played a role in policy formulation in the four cases. Furthermore, the selected cases are salient - and sometimes even emblematic - and are often referred to as examples; see for example Le Cordeur (2015) on South Africa and Morgan \& Weischer (2013) on Germany. A second point considered in selecting the cases was to ensure that 
the policies or programs examined were large enough in scope and ambition to demonstrate discernible effects, which also ensures that data on policies is available. That said, the latter is an issue for further research and mentioned again in section 5 of this paper.

The in-case analysis is structured along the lines of a strongly simplified model of the policy process, i.e. the policy cycle (Dunn 2012). Despite numerous critiques (Fischer et al. 2007: 55), the policy cycle is a useful tool/framework, enabling us to discuss the role of multiple objectives in the agendasetting, policy formulation, and implementation phases. The policy process implies the following four questions guiding the structure of our exploratory, short case studies: (1) Are multiple objectives pursued with the adoption of the policy? (2) Exactly how are these objectives reflected in policy design? (3) What results are visible and how are these appraised? (4) Are tradeoffs or synergies visible and do they appear to influence policy redesign or the stability of policies, or possibly even termination?

Figure 1 provides an overview of the structure of our case studies:

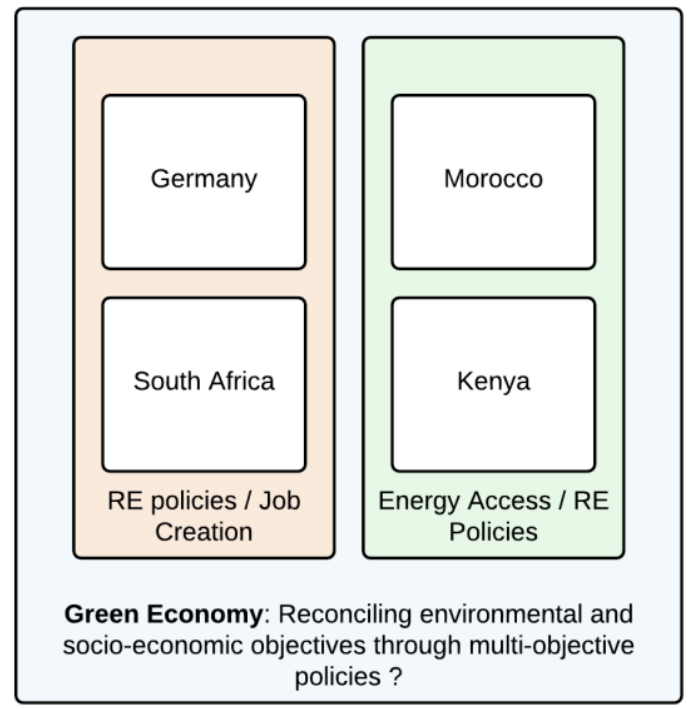

Figure 1: Case studies and focus within cases

\section{RE deployment and job creation}

\subsection{South Africa: Job creation as a core driver of RE deployment}

\section{Job creation as a key driver for the design of RE policy}

South Africa's electricity system relies on coal for well over $90 \%$ of its generation, leading to pressure to diversify in the direction of cleaner sources of energy (Alton et al. 2014). The main policy for deploying RE in South Africa is the Renewable Energy Independent Power Producer Procurement Program (REIPPPP) launched in 2011 to replace previous feed-in tariffs that were never effectively implemented (Pegels 2011). Interviewees from the public and private sector with an energy background in South Africa were asked to rank the objectives of the RE policy (for methods, see also Joas et al. in press, Steinbacher 2015). The main underlying drivers identified for the REIPPPP were 
energy security as well as job creation and industrial policy. Improving security of supply - in light of the growing incapacity of South Africa's state-owned utility ESKOM to finance and manage the addition of much-needed electricity capacity - was seen as a top driver for the program (average rank of 2.4 out of 15 objectives proposed). Only job creation was seen as an even more important policy objective (average rank of 2.2), and it was often mentioned together with the objective of industrial policy (2.5). The very strong interlinkages between socio-economic objectives and the REIPPPP were recently underlined by South African Energy Minister Tina Joemat-Pettersson, who stated that the program is designed to "contribute to economic growth and job creation, in addition to the contribution it makes to security of electricity supply" (Joemat-Pettersson 2015).

The REIPPPP is not the only reflection of socio-economic objectives in clean energy and climate policy debates in South Africa. The government's New Growth Path sets a goal of "300,000 additional direct jobs by 2020 to green the economy," with "renewable energy construction and manufactur[ing] of inputs" as main contributors (Department of Economic Development 2010). Estimates of the number of jobs created through the deployment of renewable energy in South Africa range from roughly 36,000 direct additional jobs to well over 400,000 . The maximum figure depends on how many indirect jobs are taken into account (Department of Energy 2015b: 135). The objective of creating local jobs should be viewed in the context of South Africa's 52.6\% youth unemployment rate in 2014 (increased from $50.1 \%$ in 2011) and a total unemployment rate of about one quarter of the population (World Bank 2016).

\section{The South African Renewable Energy Independent Power Producer Procurement Program (REIPPPP)}

The REIPPPP is a tender-based renewable energy procurement program, where power purchasing agreements (PPAs) for defined volumes of capacity for each technology are tendered in a two-stage process in yearly rounds (Eberhard et al. 2014). The program is notable for the important place it grants to socio-economic objectives, which are directly reflected in policy design. A particular feature of the evaluation of bids in the REIPPPP is that only $70 \%$ of points are allocated based on price, while $30 \%$ is based on other criteria targeted at achieving socio-economic policy objectives in line with development priorities and the requirements of the Broad Based Black Economic Empowerment Act (Eberhard et al. 2014, 13). One quarter of the 30 "economic development" points that bidders can earn relates to direct job creation requirements (Stands 2015, 55). Other socio-economic objectives include local content requirements, black ownership, and local economic development, which are defined in specific ways in the context of the REIPPPP (WWF South Africa: 16). The diversity and scope of economic development criteria and the direct involvement of local communities set this program apart (WWF South Africa 2015).

\section{Evaluations of the achievement of the job creation target}

The South African Department of Energy estimates that 25,526 direct jobs (one job being defined as one person-year) were created by the 1,417 MW of successful projects in bidding round three $(7,813$ jobs were available during the construction phase). This more than doubled the number of jobs created by projects from round two (Department of Energy 2015b: 135). For the fourth REIPPPP bidding round, which closed in 2015, successful projects are expected to create 27,365 person-years of direct employment over a 20 year period, of which 7,071 will be available during construction; 95.9\% of jobs are committed to be held by South African citizens (Department of Energy 2015b). 
Given the poor quality of electricity supply in South Africa and frequent blackouts that constrain economic development, the indirect effects of the REIPPPP on job creation are also expected to be positive. By adding much-needed electricity capacity within a short time-frame, solar and wind projects are expected to generate net financial benefits of 4bn ZAR in the first half of 2015 (Calitz et al. 2015).

In addition to direct job creation by REIPPPP projects, large and increasing proportions of local content in successful projects are likely to have positive effects on job creation in South Africa. Local content in PV projects in round four exceeded $64 \%$ (up from $38.4 \%$ in round 1), and the equivalent of wind is $44.6 \%$, up from $27.4 \%$ in round one (Department of Energy 2015a). The associated decrease in prices of the tenders indicates that - in the South African case - local content requirements and increasing economic efficiency can go together. The special features of the South African market (size, availability of finance, excellent resources) need to be borne in mind for the transferability of lessons to other developing countries. The question has been raised, however, as to whether the current design of REIPPPP leverages the full potential of economic development throughout the program. As pointed out by Eberhard et al. (2014: 28), the focus on value-based assessments of local content could limit the potential for job creation given that higher-value components tend to be less labor-intensive.

Beyond the official government numbers, recent studies (Eberhard et al. 2014, WWF South Africa 2015, Tait et al. 2013, Stands 2015) assess the developmental achievements of the REIPPPP. Findings from Stands' comprehensive survey on job creation in the REIPPPP (Stands 2015: 84) - the first of its kind in the South African context - indicate that the "program has exceeded all thresholds and targets set out in the bid document scorecard. Results communicated by the Department of Energy might thus underrepresent actual job creation, "leaving room for speculation and rumors about this new industry to emerge" (WWF South Africa 2015: 20). The uncertainty surrounding official job creation figures in South Africa underlines the tremendous need for further independent assessments of job creation through the REIPPPP, with continuous evaluation and monitoring. Furthermore, project companies are found to be "taking the [economic development] requirements seriously" (WWF South Africa 2015: 2; Stands 2015: 90), and to be genuinely interested in delivering the developmental aspect of their projects, given the political priority attached to job creation and local development (Stands 2015: 84).

Despite the generally positive assessment of the REIPPPP, including on dimensions other than job creation, a lack of transparent communication and consistent monitoring has led to uncertainty surrounding the achievements of the REIPPPP in the past. There has been anecdotal evidence concerning foreign renewable energy companies flying in their workforce, even for truck driver jobs. With the success of foreign utilities in bidding round three (with more than half of PV capacity won by Italian utility company Enel), this has strengthened the voice of renewable energy skeptics. Nuclear and coal activists readily point out the jobs potential in their respective industries.

"Improving lives through wind energy" reflects the industry's concern of being seen as contributing to socio-economic development through its projects. Industry stakeholders interviewed stressed that any sign of fabricated job creation expectations would put into question the future of the REIPPPP. Underlining that any policy in South Africa had to be a jobs policy above all, project developers worried about unrealistic expectations of substantial job creation and local content. At the same time auction results were expected to decrease round after round and RE projects to come online within 
short timelines. Concerns over the REIPPPP's track record seem to have waned and recent ministerial announcements point to an extension of the REIPPPP (Joemat-Pettersson 2015). The South African case nevertheless illustrates the importance of managing job creation expectations and transparent communication of achievements, both in terms of the quantity and quality of jobs (WWF South Africa 2015, Stands 2015). The limited size of the overall program and a complete lack of visibility beyond 2020 create highly challenging conditions for RE companies expected to contribute to economic development. A stronger focus on transparency, capacity development (including among project developers), and communication between stakeholders involved appears necessary to safeguard acceptance and future expansion of a renewable energy program that is expected to excel in several dimensions. Even more importantly, the lack of independent and thorough monitoring of the REIPPPP, particularly concerning the very sensitive political issue of job creation, makes an evaluation of the promise of GE challenging.

\subsection{Germany: Two stories of creating competitive advantages in RE industries}

\section{The role of jobs for renewable energy promotion}

The promotion of renewable energy (RE) in Germany was primarily driven by environmental concerns, but prospective job creation has been a welcome side effect and important political motivation. The feed-in tariff scheme (Renewable Energy Act, EEG) was set up in 2000 as the main policy for deploying RE. The main intention of it was to develop different technologies for environmental reasons ${ }^{1}$, but there was also the promise of creating new jobs. A particular concern was that the 1998 electricity market liberalization would lead to a long-term decline of RE deployment in this sector. Moreover, it was feared that decreasing energy prices would put jobs in the newly created wind industry at risk (Lauber \& Mez 2004; Jacobsson \& Lauber 2006). Employment, however, has never been an official objective in the underlying EEG Act. This was recently reemphasized by the German Government (Bundesregierung 2015), which stated that it is only a welcome side effect.

Job creation as an argument and reason for RE deployment has continued to be of political relevance, even though the evidence for it is primarily implicit. The ministries in control of RE deployment have continuously commissioned studies to analyze the impact on job creation, suggesting that they view it as a politically relevant indicator. Moreover, the number of jobs created was also highlighted in the recent Energiewende monitoring report (BMWi 2015b). Finally, a survey of policy experts on the goals of the Energiewende (Joas et al. in press) suggests that jobs, together with acquiring technology and market leadership in RE technologies, still play a crucial role in the political debate. This is also because they are of use in gaining political support for RE promotion from the employed and their associations.

\section{Policy design \& complementary measures}

The fact that job creation is not an official objective is also reflected in the design of the policies. In particular, unlike the case of South Africa and many other countries (see Kuntze \& Moerenhout 2013) the EEG does not contain any explicit local content provisions that require a certain proportion of the installed plant to be produced domestically. The only action that had been taken in this regard were

\footnotetext{
${ }^{1}$ Since then other measures have been introduced, but the EEG definitely remained the most important one.
} 
trade sanctions imposed at the EU level in 2013 to keep at bay the "dumped and subsidized imports of solar panels from China" (EC 2015) which were backed by the German government.

There have, however, been a number of complementary measures of economic promotion - explicit and implicit - from both the federal and state governments to foster job creation and industry development through the deployment of renewables. These measures comprise financial tax incentives, favorable custom duties, export credit assistance, quality certification, and different forms of loans; see Lewis \& Wiser (2007) and Kuntze \& Moerenhout (2013). Data on such measures is, however, sparse and unsystematic except for the official funds provided for energy R\&D by the federal and state governments (see BMWi 2015a). The total financial volume of all measures together is unclear, but it is very likely dwarfed by the 16 billion EUR in EEG expenditures in the same year (BDEW 2015).

\section{Impacts of RE expansion on jobs}

Figure 2, based on Lehr et al. (2015), shows gross employment through the deployment of RE for selected years in the period from 2004 through 2013. Jobs include both direct and indirect jobs: the former are jobs in companies that provide goods and services directly related to RE, for example wind turbine manufacturing, while the latter are jobs lower down the supply chain, for example production of silicon wafers (also see GIZ 2015). Estimates of net employment, i.e. the overall balance of jobs created and lost, can, however, be either positive or negative: according to Lutz et al. (2014) net job creation turned negative in the power sector, which uses by far the most RE, but this is positive in other studies (e.g. Blazejczak et al. 2013). From a societal perspective, net effects are the more relevant indicator, but they are methodologically very difficult to estimate and thus figures are relatively uncertain. Moreover, gross job effects are useful in analyzing the long-term structural effects of job creation (see Section 1). This is why we concentrate on them in the following paragraphs, focusing on the most insightful cases of wind and solar PV.

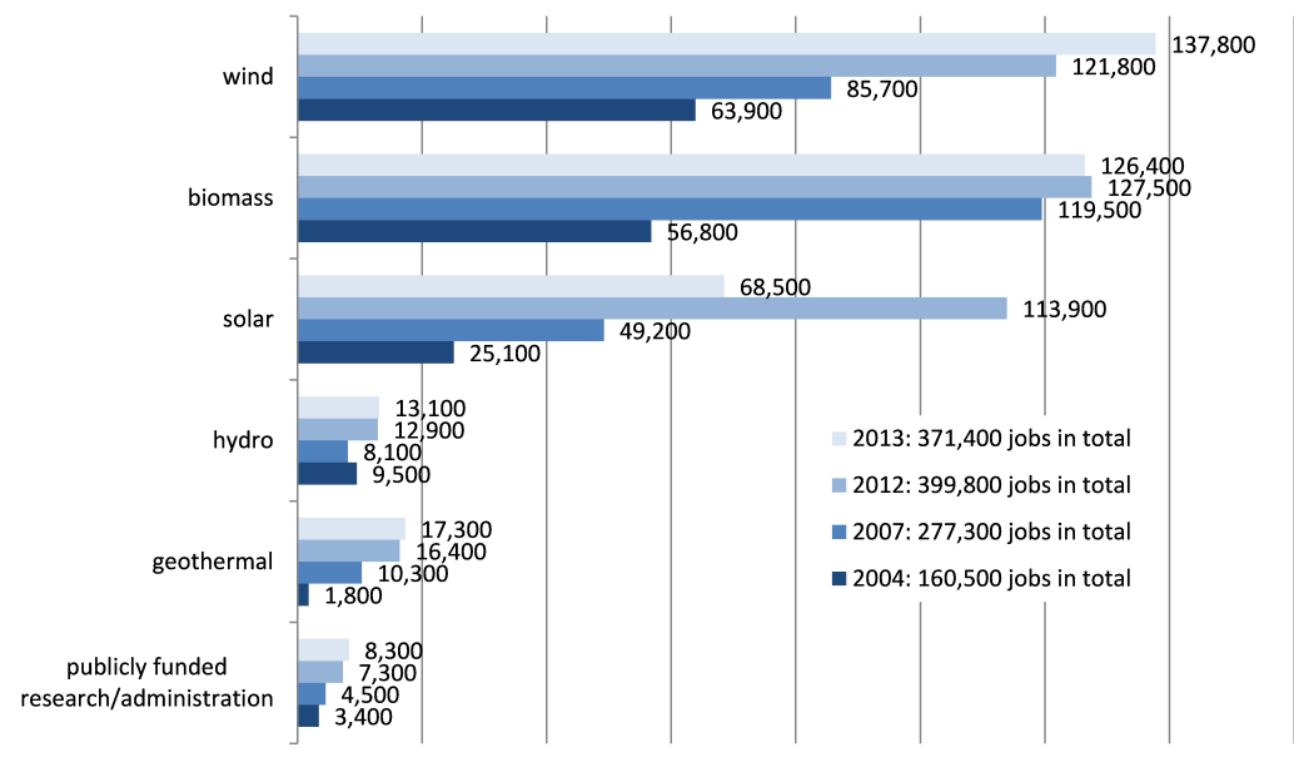

Figure 2: Estimated gross employment effects through RE in Germany (based on Lehr et al. 2015)

With regard to wind energy, the majority of jobs are related to investment, including exports (86\%). More specifically, (onshore) wind turbine manufacturing is characterized by a high proportion of 
exports (61\%) and, at the same time, a very low proportion of imports (1\%); two German companies (Siemens and enercon) have been in the global top ten for years (see Pegels \& Lütkenhorst 2014). Wind energy thus more or less resembles the prototypical case of a globally competitive industry as aspired to by (green) industrial policies.

The emblematic example of the German solar industry appears to be a more salient case, especially since it is alleged worldwide as providing evidence of failure to build up an industry. In fact, the development of employment in solar cell and module production leaves no doubt about the rise and fall of this industry. According to federal labor market statistics (see Figure 3 ) jobs in the field of module and cell production rose from around 2,000 at the beginning of 2009 to more than 12,000 in late 2011 , only to plunge back down to around 2,000 in the middle of 2014. Two related explanations are often given for this (see for example BMWi 2012; Lehr et al. 2015): (a) The surge of PV deployment made companies too optimistic regarding the future demand and considerable production overcapacities were built. Many of these capacities had to be shut down when demand for German modules and cells proved lower than expected. (b) Many new players, particularly in China, entered the world market in the late 2000s and increased competition led to an industry shake-out, which particularly affected German companies due to their cost disadvantages. This is underlined by looking at the proportion of German products installed in the German market, which fell from around $60 \%$ in 2008 to $15 \%$ in 2011 . The proportion of Chinese producers, however, rose from $21 \%$ in 2008 to $60 \%$ in 2011 (BMWi 2012).

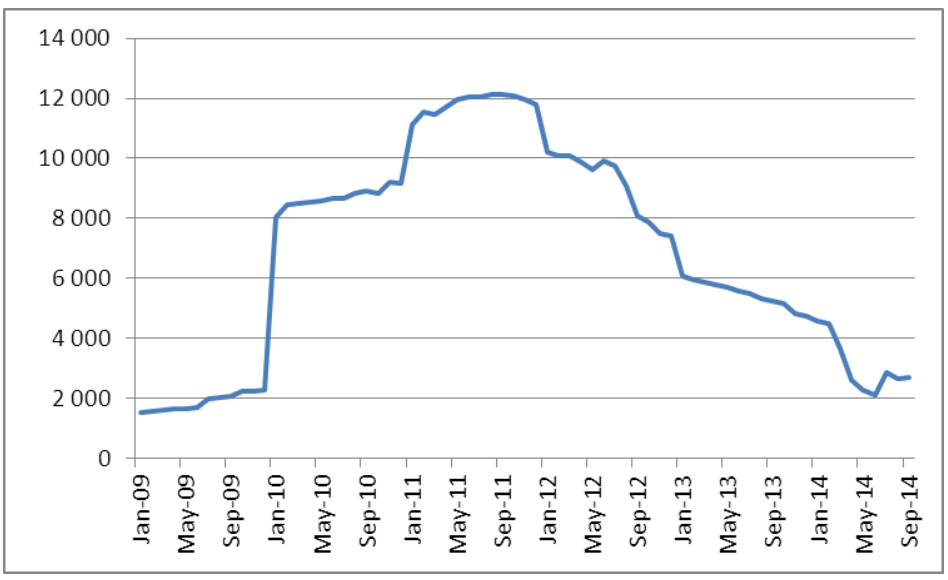

Figure 3: Jobs in solar module and cell production (Source: Destatis)

This development does not hold true for all solar industries though, as other industries higher up the value chain have fared considerably better. According to data provided by VDMA (2015) PV equipment producers as a whole provided more than $50 \%$ of the world market share in 2015 and are thus still well positioned; for a list of companies and number of employees see GTAI (2013). This confirms earlier assessments, for example by Claudy et al. (2010), according to which the prospects are particularly good in sectors where German companies are already established and have strong comparative advantages, such as manufacturing (also see wind industry above). Hence, the widespread notion that job creation has completely failed in the solar industries must be put into perspective. 


\section{Lessons and feedback of achieved effects on policy stability \& design}

In summary, Germany's record in creating and sustaining new industries and jobs through RE deployment is so far mixed. Developments in the solar cell and module production have shown that the new industries were eroded by world market competition. The more successful cases of wind energy - and in terms of absolute jobs to a lesser extent also bioenergy and other parts of the solar industry value chain - suggests that existing comparative advantages may be a decisive factor. Of course, the question of how such comparative advantages can be sustained in the long term also remains open. In particular the negative outcome in the solar industry has so far had no visible impact on RE policy design and deployment targets. The reason is presumed to be that Germany's Energiewende was never primarily a job policy and environmental concerns prevailed.

\section{Energy access polices and RE technologies}

\subsection{Kenya: Slow grid extension as a driver for market-based off-grid PV}

\section{Genesis and evolution of rural electrification plans and policies}

In 1974, the first Rural Electrification Programme (REP) was launched to increase access to electricity in rural areas in Kenya. Early progress was slow, as estimates from a 1993 survey suggest that household electricity access among rural households was about 3\% (see Table 1) (NCPD et al. 1994). In 1997, the first Rural Electrification Masterplan was developed to plan, prioritize, and accelerate rural electrification in Kenya. However, progress continued at a very slow pace. Estimates from a 2003 national survey suggest that rural household access to electricity had crept up to only $4.6 \%$ (CBS et al. 2004). Other national sources suggest that rural electrification stood at about $2 \%$ at the turn of the millennium (Karekezi \& Kithyoma 2002). The Rural Electrification Masterplan was updated in 2009 and envisaged rapid expansion of on-grid capacity. However, household electrification rates in rural areas remain very low; the most recent estimates suggest that it was less than $13 \%$ in 2013 (KNBS 2014).

As part of Kenya's vision 2030, the Rural Electrification Authority (REA), which is mandated to accelerate the pace of rural electrification, has now set a target of increasing connectivity to $100 \%$ by 2030 with an interim goal of over 50\% by 2022 (Government of Kenya 2012). This means the pace of providing new connections each year needs to increase significantly. With on-grid connection costs remaining out of reach for most poor rural customers, how this will be achieved remains unclear.

\section{Evolution and drivers of residential solar home systems (SHS) in rural electrification plans and policies}

Initial interest in renewables emerged after the oil crises of the 1970s and was motivated by a desire to reduce the cost of national oil imports and increase national energy sovereignty and resilience (Karekezi \& Kithyoma 2002). However, while these incentives still underlie the government's new plans to rapidly expand on-grid (primarily geothermal-based) renewable electric capacity, the off-grid solar PV sector is largely excluded from recent policies and plans.

The development of the solar PV sector in rural Kenya was initiated in 1984 by two ex-U.S. Peace Corps volunteers. They were instrumental in attracting interest from donors and the Kenyan 
government by organizing a number of demonstration projects showcasing PV systems in Kenya, (Byrne 2009). At the time, the government strategy for the off-grid SHS sector was one of no policy, i.e. to leave it largely unregulated. In 1986, indirect policy measures in the form of exemption from value-added tax (VAT) and duties on imported PV products and components were implemented. Since then, however, taxes and duties have been applied and removed many times and at different rates, and on different parts of PV systems (Byrne et al. 2014). More recently, since 2012, regulations for the PV sector have also come into force in the form of licensing and technical standards. On the whole, while government documents have continued to refer to solar energy, there have been few incentives and no specific targets or legislations designed to increase its uptake.

Climate change or environmental considerations appear to have neither explicitly nor implicitly motivated the SHS market development in Kenya. According to several scholars, solar PV market growth in rural areas was tied to the slow pace of grid extension and lack of confidence in the government's ability to honor its rural electrification targets (Bawakyillenuo 2012; Jacobson 2007; Acker \& Kammen 1996). The dramatic drop in PV prices together with increasing demand for electricity from better-off rural plantation workers and a growing rural middle class have also contributed. The availability of batteries manufactured locally has also been credited as having a positive impact.

While much of the literature on SHS in Kenya points to the private market-driven nature of the sector, recent analysis challenges this view and asserts that indirect public policy support and donor support were vital to building markets, absorbing risks, and developing actor networks that were key to the growth of the sector in Kenya (Byrne et al. 2014; Newell et al. 2014; Bawakyillenuo 2012). Donor support in the form of the photovoltaic market transformation initiative (PVMTI) implemented by the World Bank between 1998 and 2008, with a total budget of US\$ 5 million, was particularly important for the development of the sector. The funds were used to provide technical assistance, particularly in the areas of training and quality assurance (Hansen et al. 2014). In addition, bilateral donors such as GIZ also contributed by providing direct financial resources and by creating the supporting industry and supply-side conditions to promote market development (Bawakyillenuo 2012).

\section{Targets and achievements: SHS and rural household electrification}

Data on progress with rural electrification and SHS installations in Kenya over the last couple of decades is provided in Table 1 below. The REA has set specific targets for rural electrification in its strategic plan. The plan includes three phases: Phase I from 2008-2012, with targets for connecting all public facilities and one million rural customers and increase connectivity to 22\%; Phase II from 2013-2022 aiming to increase connectivity to 65\%; and Phase III for 2022-2030 aiming to increase connectivity to $100 \%$. As can be seen from the table, the targets for rural customer connectivity have not been achieved for Phase I.

Monitoring and evaluation activities providing insights on experiences with PV for household uses or reliability and quality of grid-connected power supply in Kenya remain extremely limited. However, some studies indicate that between a fifth and a quarter of installed SHS in Kenya in the past were not functional or only partially functioning (Acker \& Kammen 1996). Erratic equipment quality and installation and maintenance standards have been cited as some of the reasons for this. The popularity of the new fee-for-service and pay-as-you-go business models in the SHS market shift the 
responsibility for maintenance and quality assurance to the service providers, which might be of benefit to customers. However, the systems have not been in place long enough or deployed at a scale sufficient to allow a more systematic evaluation of their merits and impacts.

Table 1: Rural electricity connections and SHS deployment in Kenya

\begin{tabular}{|l|l|l|l|}
\hline Year & $\begin{array}{l}\text { Grid-connected } \\
\text { rural consumers } \\
(\text { numbers })^{1)}\end{array}$ & $\begin{array}{l}\text { Estimated total* } \\
\text { installed SHS } \\
\text { (numbers) }^{2)}\end{array}$ & $\begin{array}{l}\text { Rural household } \\
\text { electricity access } \\
(\%)^{3)}\end{array}$ \\
\hline 1993 & n.a. & 20,000 & 3.4 \\
\hline 1998 & 48,949 & 66,500 & 4.3 \\
\hline 2003 & 87,175 & 150,000 & 4.6 \\
\hline 2008 & 205,287 & 260,000 & 8.1. \\
\hline 2013 & 528,552 & 350,000 & 12.6 \\
\hline
\end{tabular}

Sources: 1) Kenya Power (various); 2) Estimated from Ondraczek 2013; 3) NCPD et al. 1994, CBS et al. 2004, KNBS 2014; Note * includes rural, urban and institutional.

\section{Changes to plans and policies and future outlook}

Kenya's new energy policy does not define any goals for further promoting SHS. Even support for ongrid solar appears to be lacking as the most recent Least Cost Power Development Plan (LCPDP) assumes that it is not cost competitive with other generation technologies. The most specific intentions for PV, concerning rural access goals, relate to the program for rural institutions and the conversion of a number of large remote diesel installations to diesel-PV hybrid systems (Byrne et al. 2014). More recent developments in energy policy-making in Kenya thus appear to have reversed even the few indirect policies aimed at supporting the SHS market. Economic considerations and the need to raise government revenues has led to the abolition of the tax and duty exemptions on PV products and components and even given rise to new taxes on some components (Byrne et al. 2014).

\subsection{Morocco: A utility-led effort to electrify remote villages off the grid}

\section{Genesis and evolution of rural electrification plans and policies}

Starting with the creation of a special energy fund in 1975, rural electrification in Morocco was carried out through the National Rural Electrification Program (Programme National d'Electrification Rurale: PNER). The first two phases of the PNER from 1982-1986 and 1991-2000, show very slow progress (Karekezi \& Kithyoma 2002). A national survey from 1992 suggests that access to electricity among rural households was $15.6 \%$ (Ministère de la Santé Publique \& Macro International 1993). The low financial capacity of the regional autonomous bodies, who were supposed to finance the program, was considered a shortcoming (Nygaard \& Dafrallah 2015).

To overcome this situation and accelerate rural electrification, in July 1995 the Global Rural Electrification Program (Programme d'Electrification Rurale Globale: PERG) was established. At the time when the PERG was launched in 1996, official sources indicated that Morocco's rural electrification rate was $18 \%$ and that the country aimed to bring the rate of rural electrification to $80 \%$ by 2010 . Since objectives were exceeded in the early years of activity, they were revised to 
electrify all the rural areas by the year 2007. The pace of electrification was also accelerated to target 1,500 to 2,000 villages per year with an estimated annual budget of 150 million dollars.

The PERG is widely considered an example of a successful rural electrification program, though many authors studying the case have had to rely on the National Office of Water and Electricity's (Office Nationale de L'Electricité et de l'Eau potable, ONEE's) ${ }^{2}$ own evaluations and data on performance and impacts (Nygaard \& Dafrallah 2015). Nevertheless, the program is responsible for increasing the rural electrification rate from $18 \%$ in 1996 to over $90 \%$ by 2013 . Building an extensive national village database for efficient prioritization of actions, detailed grid planning, and clear contractual arrangements with local governments are all cited as being factors responsible for the success of this program. A participative financing scheme in which those who benefited contributed $25 \%$ of the cost of electrification, local governments contributed $20 \%$, and ONEE picked up the remaining $55 \%$ of the cost (part of which was financed from a $2.25 \%$ solidarity tax on electricity sales) was also considered an important aspect of the program (Karekezi et al. 2005). A significant part (estimated at close to half) of ONEE's contribution to the program was mobilized from international lenders (AFD, IDB, JBIC, EIB, FADES, Kuwait Fund, KfW) as concessional loans guaranteed by the Moroccan government (Massé 2010).

\section{Evolution and drivers of residential SHS in rural electrification plans and policies}

During the early years of the PERG, the national village database assessment suggested that about 8 to $10 \%$ of rural villages were too remote and, therefore, it was too expensive to electrify them through an extension of the grid. Thus, it was foreseen that these villages would be served by decentralized PV solar home systems. In 1998, the first major PV SHS initiative, funded by the GEF and IFC, was initiated (Mostert 2008). Concerns regarding the coverage and speed of SHS dissemination, as well as adequate repairs and maintenance of the systems, led ONEE to decide to outsource the off-grid component of its rural electrification program to private contractors. Through an international bidding process, enterprises were selected for ten-year concessions and contracted to supply and maintain a fixed number of PV systems in certain specified remote regions (Christensen et al. 2015). The systems were supplied on a fee-for-service basis with households having to contribute about $10 \%$ of the cost as a connection fee and a regular monthly maintenance fee. The fee amount was determined by the type of service (size of the system) and was to be paid for over a period of 10 years (Allali 2011; Nygaard \& Dafrallah 2015). After awarding the first concession in 2002 , four other concessionaires were included in successive bidding rounds. In total, contracts were signed to distribute 105,000 SHS installations of an initial estimated 150,000 SHS envisaged when PERG was launched in 1997. International donor funding was also very instrumental in supporting the SHS deployment that became part of the PERG to provide access in remote areas (Nygaard \& Dafrallah 2015).

The primary motivation of the Moroccan government in including off-grid SHS as part of its rural electrification strategy was economic (Amegroud 2015). SHS dissemination was limited to very remote rural regions where extension of the grid was considered too expensive. However, subsequently, realizing the climate benefits of the SHS, the program was proposed for funding under the Clean Development Mechanism and was registered as one of the first programmatic CDM

${ }^{2}$ ONEE (formerly: Office national de l'électricité, ONE) is a vertically integrated, state-owned utility and the only buyer of electricity in Morocco. Moreover, it also supplies $41 \%$ of all electricity from its own plants and is thus said to dominate the power sector in Morocco (IEA 2014). 
projects (Nygaard \& Dafrallah 2015). For most of the rural population, however, electricity access has been achieved through connection to the grid (see Table 2).

\section{Targets and achievements: SHS and rural household electrification}

Data on outcomes, achievements, and impacts of the rural electrification program (PEERG) and its SHS component are exclusively available from official ONEE reports. Nygaard \& Dafrallah (2015) suggest that the estimates of the rate of rural electrification are likely to be based on coverage rather than on an estimate of actual household connections. Even so, they suggest that rural household access in 2013 is likely to be in the order of $89 \%$ (compared to the $98 \%$ suggested by ONEE's estimates of coverage).

Table 2: Rural electricity connections and SHS installations in Morocco

\begin{tabular}{|l|l|l|l|l|}
\hline Year & $\begin{array}{l}\text { Grid-connected } \\
\text { rural consumers } \\
\text { (numbers) }\end{array}$ & $\begin{array}{l}\text { Estimated total } \\
\text { installed SHS } \\
\text { (numbers) }\end{array}$ & $\begin{array}{l}\text { Rural } \\
\text { electrification } \\
\text { coverage (\%) }^{1)}\end{array}$ & $\begin{array}{l}\text { Rural household } \\
\text { electricity access } \\
(\%)^{2)}\end{array}$ \\
\hline 1993 & n.a. & n.a. & $18 \%$ & $15.6 \%$ \\
\hline 1998 & 286,899 & 1885 & $32 \%$ & n.a. \\
\hline 2003 & 979,489 & 10,457 & $62 \%$ & $51.3 \%$ \\
\hline 2008 & $1,815,047$ & 51,509 & $95.4 \%$ & n.a. \\
\hline 2013 & $2,027,120$ & 51,559 & $98.5 \%$ & $\sim 89 \%^{3)}$ \\
\hline
\end{tabular}

Sources: 1) Reproduced from Nygaard \& Dafrallah (2015) based on official ONEE's statistics; 2) Ministère de la Santé Publique \& Macro International (1993); 3) Ministère de la Santè et al. (2003). 4) Best estimate from Nygaard \& Dafrallah (2015).

Independent evaluations of the SHS component of PERG are also missing. It remains unclear why only half of the 105,000 SHS installations targeted through the concessions have been implemented, especially considering that this represents an even smaller fraction of the 150,000 originally estimated as being required. Nygaard \& Dafrallah (2015) speculate that consumers might have considered the SHS a second-best option, providing poorer service at too high a cost. This appears to be borne out by the fact that as of 2010, ONEE has embarked on a program to connect households to the grid in areas already provided with SHS (Christensen et al. 2015) and ceased the deployment of SHS in 2009. Unfortunately, no information or evaluations exist regarding the quality and performance of the SHS installed.

\section{Changes to plans and policies and future outlook}

The Moroccan government has set ambitious targets to diversify its electricity mix and reduce dependence on imports. In its 2009 National Energy Strategy, renewable energy targets were set to achieve two GW each for solar, wind, and hydropower respectively by 2020 (42\% of the total electricity capacity in 2020). However, these targets have been set for the construction of mediumto large-scale power plants; decentralized energy supply is not considered a core element in the Moroccan Solar Plan or the Moroccan Integrated Wind Energy Programme (Vidican 2015). The key incentive for this emphasis on large-scale renewables appears to be a desire to increase energy independence. However, it also aims to attract investments, build technical expertise, and improve 
industrial competitiveness (Steinbacher 2015; Vidican 2015; Marquardt et al. 2015). After years of debate and increasing pressure from Moroccan companies, the government adopted a PV roadmap at the end of 2014. In December 2015, a law (Loi 58-15) was eventually passed that will open the low-voltage grid level and thereby enable the connection of smaller scale RE installations. This is also expected to make a significant contribution to other socio-economic objectives such as job creation.

\section{Discussion}

In this section we reflect upon and discuss the implications of the findings of each case study for the GE conceptual framework. In Kenya and Morocco, renewable energy policies targeted the expansion of energy access arising from a failure to provide infrastructure. Both cases emphasize that governments have an important role in the implementation of a GE. In the Kenyan case, where the development of SHS was more market driven, existing assessments suggest that indirect government policies and donor finance had an important role to play. This case particularly highlights the need to put in place an effective regulatory framework with long-term targets. Without such a framework, deployment could subside over time or certainly not keep pace with targets or requirements. Related to this is the necessity to build up capacity both for policy-making and monitoring. The availability and reliability of policy reports and data for Kenya was relatively scarce. This, of course, makes assessing policies, including the socio-economic effects, very challenging, and highlights the need to strengthen national monitoring and evaluation capacities.

The case of Morocco is interesting in comparison because a relatively strong policy framework, with especially clear long-term targets, was put in place and the rural electrification program has been widely considered a success. Importantly, renewable deployment was largely inspired by economic, rather than environmental (green), considerations. The aim was to provide access to very remote villages that were considered too expensive to connect to the grid. Nevertheless, , the fact that SHS led to an increase in access underlines that renewable deployment can indeed create short-term socio-economic benefits and thus supports the main assertion of strong green growth (see above). This is specifically the case when important infrastructure such as grid connections is underprovided (see Introduction). Recent plans of the utility to connect regions originally covered by the SHS concessions to the central grid, suggest, however, that these are increasingly being viewed as a transitional technology. Accordingly, the socio-economic benefits from the initial renewable deployment are not likely to be sustained in the long run. However, the experience with off-grid solar may have been one factor prompting plans for more large-scale solar development that are part of current policies in Morocco. In other words, this might have helped develop "green" technologies from a niche to a more encompassing, national-level project.

The South African REIPPPP illustrates how socio-economic objectives can be strongly reflected in the design of policies for the deployment of renewables. Job creation is a particularly pressing problem in South Africa, which makes it a prototypical case for GE. Political expectations for job creation through the REIPPPP were very high and even though first reports point to a fulfillment or even overfulfillment of the creation of jobs promised by the developer, there is great uncertainty surrounding actual effects as estimated in official figures. Negative policy feedback, due to high expectations, unclear estimates of impacts, and a lack of available data and independent evaluation, are particular challenges for the assessment of South African GE concepts. These challenges seem to be typical for multi-objective policies interlinking environmental and socio-economic objectives, but have hardly 
been addressed in the GE literature. New approaches are only beginning to emerge, such as the framework developed by Sreenivas et al. (2015).

The case of Germany is interesting in comparison because employment objectives also played an important role in renewable energy policy, but only unofficially. Job creation was not reflected in policy design and no local content provisions were included. Nevertheless, expectations were high, particularly regarding the creation of technology leadership and respective jobs in the solar PV industry. Deployment of renewables was conceived, at least implicitly, as a green industrial policy. Accordingly, the German experience constitutes a test case for the strong green growth assertion, which upholds that the creation of competitive advantages in green technologies is one way to create both short- and long-term economic benefits, such as jobs. However, while the solar module and cell manufacturing industry indeed rose to global market leadership from 2009, it experienced a considerable fall only two years later, with a corresponding decline in the number of jobs. This was the result of a global industry shake-out following increased competition in combination with little pre-existing comparative advantages; in fact, this was predicted as a possible outcome by earlier theoretical literature on job market effects. Accordingly, the case of the German solar industry questions this aspect of the possibility of (strong) green growth. This must be put somewhat into perspective, though, because in comparison the wind industry has fared considerably better. Moreover, it is also possible that a dedicated multiple-objective design might have prevented this outcome.

\section{Conclusion}

This multiple-case study produced several findings suggesting that the GE conceptual framework needs to be reconsidered. First, in support of earlier findings we can confirm that the role of governments in implementing a long-term GE regulatory framework is of utmost importance. This may be particularly challenging in countries like Kenya, where capacity for policy making, monitoring and evaluation of complex policy frameworks needs to be strengthened. Accordingly, capacity building is an important enabling condition to leverage the potential for GE policies and GG and should to be addressed head on.

Second, some cases suggest that renewable deployment can generate short-term socio-economic benefits, which supports the assertion of strong green growth. They also suggest, however, that these benefits may not be sustained; energy access through SHS may eventually be superseded by grid access as in Morocco, and jobs created might be lost with the rise of international competition as in Germany. Whether the benefits could - or should - become more permanent through different policy designs remains an open question. It also needs to be acknowledged, however, that the expectation of socio-economic benefits seems to have created political momentum to implement the respective "green" policies in the first place. In Germany, green policies persist despite ambiguous job creation results in some segments, while experience with SHS in Morocco has facilitated national RE policy developments.

Finally, and probably most importantly and novel, this work suggests that designing - and analyzing policies aiming to achieve multiple objectives differs considerably from the traditional ideal-type view of policies as being targeted at single objectives. This is particularly relevant for the GE, as - at least in our understanding - it ultimately entails a "paradigmatic shift" towards such multi-objective settings. More precisely, as this paper has underlined, there is a direct interplay between renewable 
deployment and socio-economic objectives that works in two directions (Figure 4); renewable

2 deployment policies have impacts on socio-economic objectives, but these objectives also influence

3 the design and evaluation of these policies, which in turn also influences impacts throughout the

4 policy cycle.

5

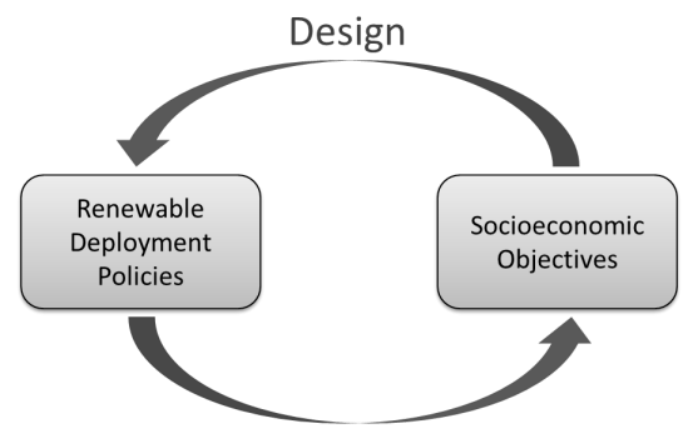

Impact \& Evaluation

Figure 4: Inter-linkage between renewable deployment policies and socio-economic objectives

This second aspect has received little attention so far. We agree with Sreenivas et al. (2015) that there has been much rhetoric while the development of practical methodologies has lagged behind. Adding to the approach they propose, our findings suggest some additional elements that could be important, namely the explicit identification of objectives, clear communication and management of expectations, and a broad and transparent set of indicators for monitoring and evaluation. The availability of sound and comprehensive data is crucial not only for further GE research, but also to ensure regulatory stability and sustainable policies. Tremendous opportunities for further research exist in order to advance our understanding of the extent to which the GE can actually achieve its promise. 


\section{References}

2 Acker, R.H. \& Kammen, D.M., 1996. The quiet (energy) revolution. Energy Policy, 24(1), pp.81-111.

Allali, B., 2011. TEMASOL: Providing Energy Access to Remote Rural Households in Morocco. UNDP.

Alton, T., Arndt, C., Davies, R., Hartley, F., Makrelov, K., Thurlow, J. \& Ubogu, D., 2014. Introducing carbon taxes in South Africa. Applied Energy, 116, pp.344-354.

Amegroud, T., 2015. Morocco's Power Sector Transition: Achievements and Potential. IAI Working Papers 15.

Azimoh, C.L., Klintenberg, P., Wallin, F. \& Karlsson, B., 2015. Illuminated but not electrified: An assessment of the impact of Solar Home System on rural households in South Africa. Applied Energy, 155, pp.354-364.

Barbier, E. \& Markandya, A., 2013. A New Blueprint for a Green Economy, New York: Routledge.

Bawakyillenuo, S., 2012. Deconstructing the dichotomies of solar photovoltaic (PV) dissemination trajectories in Ghana, Kenya and Zimbabwe from the 1960s to 2007. Energy Policy, 49, pp.410421.

BDEW, 2015. Erneuerbare Energien und das EEG: Zahlen, Fakten, Grafiken (2015), Berlin: BDEW.

Blazejczak, V.J., Diekmann, J., Edler, D., Kemfert, C., Neuhoff, K. \& Schill, W., 2013. Energiewende erfordert hohe Investitionen. DIW Wochenbericht, No. 26.

BMWi, 2012. Bericht des Bundesministeriums für Wirtschaft und Technologie zur Lage der deutschen Photovoltaikindustrie. Federal Ministry for Economic Affairs and Energy, Berlin, Germany.

BMWi, 2015a. Bundesbericht Energieforschung 2015. Federal Ministry for Economic Affairs and Energy, Berlin, Germany.

BMWi, 2015b. Die Energie der Zukunft. Vierter Monitoring-Bericht zur Energiewende. Federal Ministry for Economic Affairs and Energy, Berlin, Germany.

Bowen, A. \& Hepburn, C., 2014. Green growth: An assessment. Oxford Review of Economic Policy, 30(3), pp.407-422.

Bowen, A. \& Kuralbayeva, K., 2015. Looking for green jobs: the impact of green growth on employment. Policy brief, LSE, London and GGGI, Seoul.

Bundesregierung, 2015. Antwort der Bundesregierung auf die Kleine Anfrage der Abgeordneten Dr. Julia Verlinden, Oliver Krischer, Christian Kühn (Tübingen), weiterer Abgeordneter und der Fraktion BÜNDNIS 90/DIE GRÜNEN. German Government.

Byrne, R., Ockwell, D., Urama, K., Ozor, N., Kirumba, E., Ely, A., Becker, S. \& Gollwitzer, L., 2014. Sustainable energy for whom? Governing pro-poor low carbon pathways to development: lessons from solar PV in Kenya. STEPS Working Paper 61, Brighton: STEPS Centre.

Byrne, R.P., 2009. Learning drivers: rural electrification regime building in Kenya and Tanzania. DPhil Thesis, University of Sussex, UK.

Calitz, J., Mushwana, C. \& Bischof-Niemz, D.T., 2015. Financial Benefits of Renewables in South Africa in 2015. CSIR Energy Centre, Slides, available from http://www.csir.co.za/media_releases/docs/Financial\%20benefits\%20of\%20Wind\%20and\%20P V\%202015.pdf. 
CBS, MOH \& ORC Macro, 2004. Kenya Demographic and Health Survey 2003, Calverton, Maryland: Central Bureau of Statistics Kenya, Ministry of Health Kenya, ORC Macro.

Chaurey, A. \& Kandpal, T.C., 2010. Assessment and evaluation of PV based decentralized rural electrification: An overview. Renewable and Sustainable Energy Reviews, 14(8), pp.2266-2278.

Christensen, J.M., Mackenzie, G.A., Nygaard, I. \& Pedersen, M.B., 2015. Enhancing Access to Electricity for Clean and Efficient Energy Services in Africa. UNEP DTU Partnership.

Claudy, P., Gerdes, M. \& Ondraczek, J., 2010. Die deutsche Photovoltaik-Branche am Scheideweg. Herausforderungen und Chancen für Unternehmen entlang der Wertschöpfungskette. pwc.

Le Cordeur, M., 2015. South Africa set to become global leader of green energy. Available at: http://www.southafrica.info/business/economy/infrastructure/renewables170415.htm\#.VxViXccrzww\#ixzz46DkACQmn [Accessed April 20, 2016].

Dai, H., Xie, X., Xie, Y., Liu, J. \& Masui, T., 2016. Green growth: The economic impacts of large-scale renewable energy development in China. Applied Energy, 162, pp.435-449.

Daly, H., 2013. A further critique of growth economics. Ecological Economics, 88, pp.20-24.

Deichmann, U., Meisner, C., Murray, S. \& Wheeler, D., 2011. The economics of renewable energy expansion in rural Sub-Saharan Africa. Energy Policy, 39(1), pp.215-227.

Department of Economic Development, 2010. The New Growth Path: The Framework. Department of Economic Development, South Africa.

Department of Energy, 2015a. Renewable Energy IPP Procurement Programme. Bid Window 4 Preferred Bidders' Announcement. Department of Energy, South Africa.

Department of Energy, 2015b. State of Renewable Energy in South Africa. Department of Energy, South Africa.

Dunn, W.N., 2012. Public Policy Analysis, New York: Pearson.

Eberhard, A., Kolker, J. \& Leigland, J., 2014. South Africa's Renewable Energy IPP Procurement Program: Success Factors and Lessons. PPIAF, Washington DC, USA.

EC, 2015. The European Union's measures against dumped and subsidised imports of solar panels from China. European Comission.

Fankhauser, S., Sehlleier, F. \& Stern, N., 2008. Climate change, innovation and jobs. Climate Policy, 8(4), pp.421-429.

Fischer, F., Miller, G.J. \& Sidney, M.S., 2007. Handbook of Public Policy Analysis: Theory, Politics, and Methods, Boca Raton, FL: CRC Press.

George, A.L. \& Bennett, A., 2005. Case Studies and Theory Development in the Social Sciences, Cambridge, MA: MIT Press.

Gerring, J., 2004. What Is a Case Study and What Is It Good for? American Political Science Review, $98(2)$.

GIZ, 2015. Green Jobs: Impacts of a Green Economy on Employment. GIZ.

Government of Kenya, 2012. Vision 2030 Document, Nairobi, Kenya: Government Printers. 
GTAI, 2013. Photovoltaic Equipment. GTAI, Berlin Germany.

Hansen, U.E., Pedersen, M.B. \& Nygaard, I., 2014. Review of Solar PV market development in East Africa. UNEP Ris $\varnothing$ Centre Working Paper, no. 12.

IEA, 2013. World Energy Outlook 2013, Paris: International Energy Agency.

IOB, 2014. Access to Energy in Rwanda Impact evaluation of activities supported by the Dutch Promoting Renewable Energy Programme. IOB Evaluation, no. 396.

IPCC, 2014. Climate Change 2014: Mitigation of Climate Change. Contribution of Working Group III to the Fifth Assessment Report of the Intergovernmental Panel on Climate Change, New York: Cambridge University Press.

IPCC, 2012. Renewable Energy Sources and Climate Change Mitigation. Special Report of the Intergovernmental Panel on Climate Change, New York: Cambridge University Press.

IRENA, 2016. Renewable Energy Benefits: Measuring the Economics. IRENA, Abu Dhabi.

Jacobs, M., 2013. Green Growth. In R. Falkner, ed. The Handbook of Global Climate and Environment Policy. Oxford: Wiley-Blackwell, pp. 197-214.

Jacobson, A., 2007. Connective Power: Solar Electrification and Social Change in Kenya. World Development, 35(1), pp.144-162.

Jacobsson, S. \& Lauber, V., 2006. The politics and policy of energy system transformation-explaining the German diffusion of renewable energy technology. Energy Policy, 34(3), pp.256-276.

Jakob, M. \& Edenhofer, O., 2014. Green growth, degrowth, and the commons. Oxford Review of Economic Policy, 30(3), pp.447-468.

Joas, F., Pahle, M., Flachsland, C. \& Joas, A., Which goals are driving the Energiewende? Making sense of the German Energy Transformation. Energy Policy, in press.

Joemat-Pettersson, T., 2015. Expansion and Acceleration of the Independent Power Producer Procurement Programme. Media Statement Issued by the Department of Energy on 16 April 2015.

Jürisoo, M., Pachauri, S., Johnson, O. \& Lambe, F., 2014. Can low-carbon options change conditions for expanding energy access in Africa? Discussion Brief, SEI and IIASA, (April).

Karekezi, S. \& Kithyoma, W., 2002. Renewable energy strategies for rural Africa: is a PV-led renewable energy strategy the right approach for providing modern energy to the rural poor of sub-Saharan Africa? Energy Policy, 30(11-12), pp.1071-1086.

Karekezi, S., Majoro, L., Kimani, J. \& Wambile, A., 2005. Ring-fencing Funds for the Electrification of the Poor: Lessons for Eastern Africa. Sub-Regional "Energy Access" Study of East Africa. Prepared for "Energy Access" Working Group Global Network on Energy for Sustainable Development.

Kenya Power, various. Annual Reports, Nairobi, Kenya: Kenya Power.

KNBS, 2014. Kenya Demographic and Health Survey 2014, Nairobi, Kenya: Kenya National Bureau of Statistics.

Kuntze, J. \& Moerenhout, T., 2013. Local Content Requirements and the Renewable Energy Industry A Good Match? ICTSD, Geneva, Switzerland. 
Lauber, V. \& Mez, L., 2004. Three Decades of Renewable Electricity Policies in Germany. Energy \& Environment, 15(4), pp.599-623.

Lehr, U., Edler, D., O'Sullivan, M., Peter, F. \& Bickel, P., 2015. Beschäftigung durch erneuerbare Energien in Deutschland: Ausbau und Betrieb, heute und morgen. gws, DLR, DIW, Prognos, ZSW.

Levy, J., 2008. Case Studies: Types, Designs, and Logics of Inference. Conflict Management and Peace Science, 25(1), pp.1-18.

Lewis, J.I. \& Wiser, R.H., 2007. Fostering a renewable energy technology industry: An international comparison of wind industry policy support mechanisms. Energy Policy, 35(3), pp.1844-1857.

Lutz, C., Lindenberger, D. \& Kemmler, A., 2014. Endbericht Gesamtwirtschaftliche Effekte der Energiewende. gws, Prognos, EWI.

Marquardt, J., Steinbacher, K. \& Schreurs, M., 2015. Driving force or forced transition? The role of development cooperation in promoting energy transitions in the Philippines and Morocco. Journal of Cleaner Production, in press.

Massé, R., 2010. Financing Rural Electrification Programs in Africa. CLUB-ER.

Ministère de la Santè DPRF/DPE/SEIS \& ORC Macro, 2003. National Survey on Population and Health Morocco 2003-04, Rabat, Morocco.

Ministère de la Santé Publique \& Macro International, 1993. National Survey on Population and Health Morocco 1992, Rabat, Morocco.

Morgan, J. \& Weischer, L., 2013. The World Needs More Energiewende. The European. Available at: http://www.theeuropean-magazine.com/jennifer-morgan--2/6927-germanys-path-towardsrenewable-energies [Accessed April 20, 2016].

Mostert, W., 2008. Review of Experiences with Rural Electrification Agencies Lessons for Africa. EUEIPDF.

NCPD, CBS \& MI, 1994. Kenya Demographic and Health Survey 1993, Calverton, Maryland: National Council for Population and Development, Central Bureau of Statistics, Macro International.

Newell, P., Phillips, J., Pueyo, A., Kirumba, E., Ozor, N. \& Urama, K., 2014. The Political Economy of Low Carbon Energy in Kenya. IDS Working Paper 445, Brighton, UK.

Nygaard, I. \& Dafrallah, T., 2015. Utility led rural electrification in Morocco: combining grid extension, mini-grids, and solar home systems. Wiley Interdisciplinary Reviews: Energy and Environment, p.n/a-n/a.

OECD, 2010. Green jobs and skills: the local labour market implications of addressing climate change. working document, CFE/LEED, OECD.

Ondraczek, J., 2013. The sun rises in the east (of Africa): A comparison of the development and status of solar energy markets in Kenya and Tanzania. Energy Policy, 56, pp.407-417.

Palit, D., 2013. Solar energy programs for rural electrification: Experiences and lessons from South Asia. Energy for Sustainable Development, 17(3), pp.270-279.

Pegels, A., 2011. Pitfalls of policy implementation: The case of the South African feed-in tariff. In J. Haselip et al., eds. Diffusion of renewable energy technologies. Case studies of enabling frameworks in developing countries. Roskilde, Denmark: UNEP Ris $\varnothing$ Centre, pp. 101-110. 
Pegels, A. \& Lütkenhorst, W., 2014. Is Germany's energy transition a case of successful green industrial policy? Contrasting wind and solar PV. Energy Policy, 74(C), pp.522-534.

Rao, N.D., Agarwal, A. \& Wood, D., 2016. Impacts Of Small-Scale Electricity Systems: A Study of Rural Communities in India and Nepal, Washington DC: World Resources Institute.

Rathmann, R., Szklo, A. \& Schaeffer, R., 2012. Targets and results of the Brazilian Biodiesel Incentive Program - Has it reached the Promised Land? Applied Energy, 97, pp.91-100.

Recalde, M.Y., 2015. The different paths for renewable energies in Latin American Countries: the relevance of the enabling frameworks and the design of instruments. Wiley Interdisciplinary Reviews: Energy and Environment.

REN21, 2014. Renewables 2014 - Global Status Report. REN21 Secretariat, Paris, France.

Rodrik, D., 2014. Green industrial policy. Oxford Review of Economic Policy, 30(3), pp.469-491.

Sovacool, B.K., D'Agostino, A.L. \& Jain Bambawale, M., 2011. The socio-technical barriers to Solar Home Systems (SHS) in Papua New Guinea: "Choosing pigs, prostitutes, and poker chips over panels." Energy Policy, 39(3), pp.1532-1542.

Sreenivas, A., Cohen, B., Dubash, N.K., Khosla, R. \& Dukkipati, S., 2015. Towards Methodologies for Multiple Objective-Based Energy and Climate Policy. Economic and Political weekly, 50(49).

Stands, S.R., 2015. Utility-Scale Renewable Energy Job Creation: An investigation of the South African Renewable Energy Independent Power Producer Procurement Programme (REIPPPP). Master Thesis, Stellenbosch University, South Africa.

Steinbacher, K., 2015. Drawing Lessons When Objectives Differ? Assessing Renewable Energy Policy Transfer from Germany to Morocco. Politics and Governance, 3(4), pp.34-50.

Steinbacher, K., forthcoming. Exporting the Energiewende? Determinants for policy transfer from Germany to Morocco, South Africa, and California. Doctoral research project, Freie Universität Berlin.

Tait, L., Wlokas, H.L. \& Garside, B., 2013. Making communities count. Maximising local benefit potential in South Africa's Renewable Energy Independent Power Producer Procurement Programme (RE IPPPP). IIED, London, UK.

UNEP, 2011. Towards a Green Economy: Pathways to Sustainable Development and Poverty Eradication - A Synthesis for Policy Makers. UNEP.

Urpelainen, J., 2016. Energy poverty and perceptions of solar power in marginalized communities: Survey evidence from Uttar Pradesh, India. Renewable Energy, 85, pp.534-539.

VDMA, 2015. VDMA Photovoltaik-Produktionsmittel: Investitionen außerhalb Asiens ziehen an. German Engineering Federation (VDMA), available from http://pv.vdma.org/en/article//articleview/11180819.

Vidican, G., 2015. The emergence of a solar energy innovation system in Morocco: a governance perspective. Innovation and Development, 5(2), pp.225-240.

van der Vleuten, F., Stam, N. \& van der Plas, R., 2007. Putting solar home system programmes into perspective: What lessons are relevant? Energy Policy, 35(3), pp.1439-1451.

World Bank, 2016. World Development Indicators. World DataBank. Available at: http://data.worldbank.org/ [Accessed April 20, 2016]. 
WRI, 2015. Clean Energy Access In Developing Countries: Perspectives On Policy and Regulation. Issue Brief, World Resources Institute.

WWF South Africa, 2015. A review of the local community development requirements in South Africa's renewable energy procurement programme. WWF Technical Report.

Yin, R.K., 2009. Case Study Research: Design and Methods, Los Angeles, London, New Delhi, Singapore, Washington DC: SAGE Publications.

Zeyringer, M., Pachauri, S., Schmid, E., Schmidt, J., Worrell, E. \& Morawetz, U.B., 2015. Analyzing grid extension and stand-alone photovoltaic systems for the cost-effective electrification of Kenya. Energy for Sustainable Development, 25, pp.75-86. 